\title{
ECONOMIC STABILITY AND ANTITRUST POLICY
}

\author{
Henry C. Simons*
}

7 HE proponent of a largely competitive, free-market, free-enterprise system is plagued incessantly, and often discredited in de-

1 bate, by the claim that such an institutional system is, and has been, inherently and intolerably unstable. The wide fluctuations of employment, income, and production of the past are commonly attributed to competition and to decentralization of control. The facts of instability in the past are commonplace. It is likewise undeniable that industries (or better, enterprises) not characterized by effective competition have fared better in the face of general instability than have the more competitive areas of the economy (e.g., agriculture) - or, at any rate, better than they would have fared with more competition or more decentralization of control. From such evidence, the layman readily (too readily) concludes that competitive conditions mean instability, and that the remedy lies in removing competition in favor of some other instrumentality of control. The plausibility of this conclusion, moreover, has been assiduously exploited by special pleaders and apologists for innumerable producer groups. Such vulgar economic analysis is the main stock-in-trade, not only of our radicals and revolutionaries on the left but of monopolists and cartelizers on the extreme right as well-not to mention the more ingenuous advocates of "planned economy."

The answer of the radical-conservative or traditional economist liberal is that general and acute instability is, on any soundly reasoned analysis, primarily attributable to faulty monetary institutions and, in the broadest sense, to unfortunate fiscal policy. Indeed he may go further and insist that monopolistic control of prices and wage-rates has, in fact, served to aggravate monetary instability and substantially to counteract or to frustrate such soundly remedial monetary and fiscal measures as have been employed.

This, in any case, is not the place (if, indeed, there is any proper place) for examining controversial questions of business-cycle theory. For present purposes, we may concede that rigidity of monopolistic prices and wages does set limits politically, if not economically, to fluctuations of general prices (if not of output and employment). Moreover, and more important, we may concede that, failing deliberate measures of fiscal

* Associate Professor of Economics, University of Chicago. 
stabilization, there are no politically significant limits to the instability of prices and, especially, to the degree of deflation which might occur under the institutional arrangements of the past. Whether extreme instability of the price level would involve intolerable fluctuations of employment and real income, given highly competitive markets for all goods and services, is an empty, academic question; for such price-level instability is undesirable and disturbing in other decisive respects; and the degree of price and wage flexibility necessary to assure reasonable stability of production and employment in the face of great monetary instability is utterly unattainable.

The characteristics of the best scheme of financial institutions and fiscal policies remain highly controversial. However, only a small, intransigent group of academic economists would now question the imperative need for deliberate governmental action (national and supranational) to counteract the perversity of changes both in the quantity and in the velocity of effective money (deposits). The old economic system (so far as it was competitive) could be trusted systematically and automatically to correct disturbances in relative prices and relative outputs of goods and services. Unexpected changes set in motion forces which served automatically to adapt both production and prices and to reallocate resources economically. General price (price-level) movements, however, served quite as systematically to set in motion forces which served, not to correct but to aggravate the initial disturbance. Thus, the familiar phenomenon of cumulative inflation and, especially, cumulative deflation. If a free market system is to function effectively in allocating resources and in determining the composition of output, it must operate within a framework of monetary stability which it cannot create for itself and which only government can provide. This amounts only to asserting the axiom that it is a proper and minimal function of government to control (i.e., keep stable) the currency.

The kind of stability of aggregate incomes and employment which everyone desires can be attained under either of two extremes in political arrangements: (I) essentially free markets for goods and services, combined with deliberate fiscal or monetary stabilization by government; or (2) total governmental control of all production (granting that political power can be wholly concentrated, wisely exercised, and securely held by those who exercise it). The former arrangement implies political centralization of control over the value of money and close adherence to rules of fiscal policy which minimize uncertainties as to price-level changes. It also implies, inter alia, an extreme decentralization of control over prices 
and quantities of particular goods and services-a decentralization which it is also a primary function of government to foster and to preserve, in accordance with "constitutional" rules of policy. The latter arrangement (2), of course, is simply the totalitarian, collectivist state.

Particular problems of economic policy are fairly easy to formulate and to analyze for either of these two systems. Both, of course, are ideal types which have never existed, and will never exist, in a pure form. Englishspeaking nations, however, in the recent past, have lived under a system. which was close enough to the first type to warrant analysis of their policy problems as problems of that system-type. If they have been moving away from it, in terms of market organization, they have on balance perhaps been moving toward it in terms of changes in financial structure and fiscal practice. Indeed, we may well attain, for the first time, a proper financial framework for a free-market society after we have lost or abandoned the requisite deconcentration of control over relative prices and relative outputs. In any case, the question of which type of system we should now move toward presents perhaps our central question of public policy.

The decade of the thirties naturally has bequeathed to us a sense of desperate need for protection against insecurity and economic fluctuations. While irresponsible war financing should now raise the awful spectre of extreme inflation as the great danger for an indefinite future, we are still. mainly concerned about the next depression and deflation-about repetition of recent affictions of unemployment and private insolvency.

If we can face the deflation danger as a national or international problem, its solution should be relatively easy and costless. Indeed, we have perhaps left behind an era in which the main danger lay in private debt and its threat of recurrent, precipitous deflation and entered a period where great and growing government debt exposes us continuously to radical decline in money value. Recurrent desperate struggles for liquidity may be displaced by recurrent flights from the currency as the major threat to economic and political security. Similarly ominous, however, is the prospect that security and stability will increasingly be sought, not through the sound and promising devices of over-all fiscal policy but through action by and for particular producer groups.

This unhappy trend is strengthened both by extravagant optimism and by inordinate skepticism about the possibilities and prospects of monetary and fiscal control. Proponents of the new monetary doctrines tend grossly to exaggerate the potentialities of such control, confident that fiscal devices can alone solve our major problems in spite of any untoward ac- 
cumulations of governmental and private restraints upon trade. While sometimes asserting the (mistaken) view that rigid, administered, monopolistic prices and wages may facilitate over-all monetary stabilization, they usually assert that monopolistic restraints are at most relatively unimportant as an obstacle to full production. A justifiable enthusiasm for monetary reform thus leads to gross disregard for other requisites of political order and economic efficiency in a democratic society.

On the other hand, representatives of particular industries and occupations display gross skepticism about the possibilities of over-all, monetary stabilization. Against recurrence of afflictions of the thirties (admittedly of monetary origin), they demand particularist measures of protection, group by group, minority by minority. These demands are in general sympathetically received. It is seldom seriously proposed that attention be focused on over-all monetary stabilization and that, given the prospect of success at that level, each producer group should be willing and obligated to take its chances without special favors or privilege.

What strategically situated groups (farmers, suppliers of basic raw material, producers of capital goods, et al.) may reasonably demand is protection against the specially severe deprivations of general depression and deflation. This, a democratic government can and should providebut by general, monetary measures and without gross or deliberate differentiation among producer or enterpriser groups. Surely our federal government can stabilize the value of its currency if that purpose is accepted and intelligently pursued. Its power of taxing and spending are surely adequate; and their exercise to that end involves no sacrifice of other accepted values or objectives. By proper variations in its spendings and, especially, in its tax levies, it can inject and withdraw purchasing power as monetary stabilization may require. Nor does this imply or necessitate continued increase in the interest-bearing debt-or preclude the steady amortization of such existing debt.

Along these lines, it certainly is possible (and desirable) to give stability to a competitive, free-market, free-enterprise system without impairing its competitiveness, and without substituting political (monopolistic) for competition controls in the markets for particular goods and services. To attain stability for particular industries or producer groups, by particularist measures, on the other hand, requires, if not outright special subsidies, the displacement of decentralized, competitive control by central authority, governmental or private. It thus involves radical departure from our traditional institutional system and movement toward the collectivist type. Proxinately it implies further degradation of democratic govern- 
ment in the promiscuous dispensation of special privileges and immunities to organized, articulate producer minorities. Formalists will, of course, distinguish sharply between control exercised by responsible government agencies (e.g., under "commodity agreements") and control exercised by irresponsible private corporations and cartels. While dangerous in both cases, it is likely to be exercised with less disregard of the public interest by private groups, than by government agencies actually responsible to particular producer groups. There is, on balance, some advantage in having such power exercised, if at all, in a nominally irresponsible manner, since it is more likely to be exercised with restraint if precariously held.

The common public interest in over-all, monetary stabilization, national and international, is, like consumer interests generally, almost unrepresented in the political process. While opposed only by irresponsible reactionaries, it is vigorously sponsored and promoted by no one prominent in affairs. Stabilization schemes for particular producer groups, on the other hand, are powerfully represented and espoused. Thus, farm leaders push international schemes for fixing. prices, limiting ouputs, and dividing export markets by quota allocations. Producers of basic industrial materials (rubber, tin, copper, etc.) demand larger governmental participation in restrictive cartels. Cartelized manufacturers (chemicals, steel, electrical equipment, etc.) sponsor similar arrangements, demanding either governmental assistance or, at least, immunity from prosecution for monopolistic practices. In all cases, the argument runs in terms of security and stability-in terms of indispensable protection against the horrors of depression competition.

If many such special demands are granted, it is hard to see how others can be resisted or, for that matter, how we can continue to have an antitrust policy at home or any prosecution of restraint of trade. Equally hard is it to see how we can have effective economic cooperation internationally or any enduring peace. If this $i$ the wave of the future, we might well ride it deliberately, organize a trading system like that of Germany, and regard peace merely as an opportunity to prosecute trade as economic warfare, with purely military objectives!

If half the time and effort now lavished on proposed international eartels could be diverted to plans for national and international monetary stabilization, even the special-interest groups, not to mention the rest of us, would be far better served. Particularist stabilization proposals have diverted current international planning almost wholly away from its proper task or objectives. A promising beginning, to be sure, has been made in the Keynes and White Reports; but even these documents are pri- 
marily concerned with exchange rates and not with stabilization of the purchasing power of either the dollar or the pound (or of Unitas or Bancor). While properly concerned about nationalistic exchange-control and its consequences for trade, these Reports have little to say about tariffs or about the trade restraints of private monopolies. Indeed, they explicitly accept "commodity agreements." Thus, real, fundamental planning for economic stability and intermational economic cooperation under less restricted trade seems to have bogged down completely, while international monopoly schemes are burgeoning and thriving all over the place. The early talk about reducing tariff barriers has subsided completely. A possible international antimonopoly program is now moving along rapidly in reverse. And the reason is simply utter lack of responsible political leadership. Failing such leadership, the only things that have promise politically are measures on behalf of special minority interests-cartel schemes with the usual polite invitations for consumer representation. Instead of a sound international program sponsored and carefully guided in its formation by a vigorous and alert State Department, with full executive support, we have in prospect, besides a rather trivial scheme for exchange rates, only a multiplicity of proposals for extending and legitimatizing private international monopoly. The sound urge toward international cooperation is being "satisfied" and perverted in the form of broader cooperation of producer groups to raise prices and reduce outputs.

Such schemes not only divert attention from monetary stabilization and other proper forms of international economic cooperation. They also aggravate the difficulties of over-all stabilization. The attempt to sustain employment and investment by monetary devices must operate against the restriction of output and investment which is the basic function of agencies, governmental or private, for "stabilizing" particular prices. Such stabilization is almost inevitably a one-way process-raising prices which are often considered too low and seldom, if ever, considered too high.

During depressions, the stabilization of particular prices against a general decline serves to shift the burdens of depression heavily upon other groups and, thus, to increase the difficulties of effective monetary or fiscal counteraction. Sustaining such prices means larger curtailment of employment and, thus, of spending. It means drawing off a larger share of spending to the particular enterprises, and thus, deepening the depression in other areas of the economy.

Conversely, rigidity of "administered" prices during a boom is likewise mainly unfortunate-if (as in rare cartel instances perhaps has been the 
case) "stabilization" ever works both ways. If steel prices are held down during a boom, by virtue of normal excess capacity, one important check upon excessive boom-time investment is removed. (If they are held down by private rationing, the effects and purposes of the rationing devices are at least open to question.) Variation in costs of capital goods is certainly not an adequate substitute for monetary-fiscal stabilization; but one may not deny that increases would somewhat reduce boom-time investment, or that decreases would help fill in the valleys of investment during depressions. Conversely, the task of monetary stabilization will be less difficult, and perhaps better discharged, if relative prices of capital goods and their major cost elements are responsive to changes in general business conditions.

On a more realistic view of the future, however, one must focus attention upon the contributions of monopolistic wage and price controls to the difficulties of preventing or checking continued inflation. Too much attention has been directed to the influence of price and wage rigidity ("stabilization") when, in fact, the controls or "administration" work mainly or largely to prevent change only in one direction (downward). No amount of monetary or fiscal stimulation will give us adequate employment or investment, if strategically situated unions and enterpriser monopolists insist upon utilizing improved demand conditions to increase their wages and prices rather than to increase employment, investment, and outputor to hold up prices where improved technology is markedly reducing costs. And there is no reason why organized producer groups, holding adequate organizational and political power, should, acting in their separate interests, forego the opportunity to improve their relative position in such circumstances. They may, to be sure, injure themselves along with the community, all or most of them being worse off by virtue of their restrictive measures than if none had practiced them. But each group may be better off than if it alone had behaved less monopolistically; and, short of dictatorship at one extreme and real competition at the other, there would appear to be no means for getting coordinated or cooperative action from such groups as a whole.

Ultimately, as producers become more and more effectively organized, and the economy increasingly syndicalist, only internal competition or authoritarian dictation can protect organized groups from the folly of their own aggregate restraints. To argue that monetary stabilization, or even continued inflation, can overcome the restrictive efforts of widespread monopoly or bring the flexible, competitive prices reasonably into line with administered prices and wages, is to predict what is least proba- 
ble. The experience with wartime inflation, as to wage rates, farm prices, and silver politics, should facilitate better predictions, if common sense does not yield good ones. Prices and wages which are most rigid in the face of depression and deflation are likely to be most flexible in the face of inflation. In either and all circumstances, monopolistically organized and politically articulate groups may be expected to look after themselves, to serve their special interests, and mainly to act contrary to the common welfare-and even contrary to their own common interests. So, we might inflate endlessly and still find ourselves with worse maladjustments of relative prices and relative wages than we had at the start.

No amount of monetary stabilization or stimulation can make an economy function better or tolerably as it becomes increasingly monopolized and syndicalized. Restrictive measures, widely applied, must add up to serious aggregate restriction, to unemployment, and to a stagnant or contracting economy. Given widespread competition, free enterprise, and free access to markets for particular goods and services, the economy would be sensitive and responsive to monetary controls, and able to thrive on the limited measure of fiscal stimulation which is consistent with a stable price level and a stable or declining public debt.

Only in a substantially competitive economy can injections of purchasing power be counted on persistently to increase output rather than prices, employment rather than merely wage rates. Only competition can assure that prices which have been held up during deflation will not be pushed up during deliberate reflation-that those which have resisted general downward movement will not lead the way upward. To anticipate another pattern without competition is to count on stupid lethargy among the most aggressive and powerful and to suppose that groups possessing great power will not exercise it promptly and wisely in their special interest.

The main opjective in national (and supranational) policy, of course, must be adequate and stable employment. This objective, in turn, must be attained without marked or continued inflation and without recourse to beggar-my-neighbor measures of economic warfare, aggressive or defensive. To these ends, we must seek to break down all artificial barriers and inhibitions against new enterprise and private investment.

Failure in this undertaking, moreover, is likely to prove cumulative and self-aggravating. If expansion of private output and investment does not provide adequate employment, governmental enterprise and investment must fill the gap. This, in turn, necessarily involves governmental encroachment in areas of potential private investment and, thus, further 
inhibition of private capital to enter into competition with subsidized governmental enterprise. It also involves aggravation of inflation dangers and ominous threats to political and property institutions, whose security is requisite to private investment expansion.

On the other hand, failing general prosperity and expansion, particular industries and producer minorities are certain to be both more demanding and more successful in protecting and defending their relative position by exploitative, beggar-my-neighbor measures, governmental and private. Tolerating and promoting the restrictive schemes of powerful, organized minorities, we shall not only sacrifice expansion potentialities in their sphere but shall expose enterprise and investment elsewhere to their ar bitrary, monopolistic exactions.

New enterprise and investment, facing competition and irreducible uncertainties in their product markets, must be assured of access to reasonably free, competitive markets for their purchases (labor and materials). Otherwise, they face not only the inevitable risks of misdirection of their activities ("normal," competitive loss contingencies) but the forbidding prospect of forfeiting any possible profits to organized, monopolistic suppliers of things they must purchase. There obviously can be no adequate private investment in a community where such investment is, or reasonably seems to be, a giving of hostages to powerful protagonists in economic civil war. A vigorous and expanding system of private enterprise needs little, if any, pure profit on balance, to function effectively. Loss contingencies, however, must be counterbalanced by possibilities of somewhat commensurate gains; and such possibilities, for new and competitive enterprise, simply do not exist where it is surrounded by organized sellers (or faced by organized buyers). Besides the danger of having its legitimate profits appropriated by arbitrary power, there is also the risk of destruction through collusive action of its suppliers and its competitors in the product market.

There can be adequate investment and employment in a precominantly free market economy with effective monetary-fiscal stabilization or, alternatively, in a predominantly collectivist system based on securely centralized power. Full production can be achieved either by extreme concentration or extreme deconcentration of control over particular prices and outputs. Like economical allocation and proper relative prices, investments, and outputs, however, it is unattainable in the face of an undisciplined struggle of organized producer groups which usurp or abuse governmental powers separately to improve their relative positions. In any system which is orderly or prosperous, the public interest in full pro- 
duction must be protected either by competition within producer groups or by authority which compels them to accept reasonable prices and to maintain adequate output. We recognize at least vaguely the threat to world order and prosperity arising from beggar-my-neighbor policies in international economic relations. We do not recognize, save perhaps during total war, the threat to domestic order and prosperity arising from such policies on the part of functional groups organized to restrain trade or to secure special governmental restraints on their behalf. Abhorring total centralization of power, and unwilling to enforce a workable decentralization, we drift rapidly into political organization along functional, occupational lines-into a miscellany of specialized collectivisms, organized to take income away from one another and incapable of acting in their own common interest or in a manner compatible with general prosperity. Seeking security and prosperity, group by group within the econoomy, we have as little chance of obtaining these goods as we have of attaining peace among nations by analogous military measures.

We are attempting to argue here a case which seems so obvious that effective argument is difficult. The amazing thing is that anyone should entertain the opposite view. Surely a competitive economy would be extremely sensitive to monetary controls and relatively easy to stabilize by fiscal devices. That the same should be true of a highly monopolized or syndicalist system is improbable on its face and, on reflection, appears quite impossible. Monetary remedies can cure monetary ills. In excessive doses, they may serve to conceal other ills. That they should counteract or greatly ameliorate the consequences of wholesale organization of producer groups to exploit one another (and the unorganized) by raising their prices relatively and restricting their respective outputs, is certainly not

- to be anticipated on the basis of any reasoned analysis. Syndicalism cannot be transformed into an efficient and orderly scheme of politico-economic organization merely by adding a suitable monetary constitution.

Monetary and fiscal controls, aiming at stabilization of the value of money or price level, are a proper and now indispensable element in the framework of a free-market society. In such a society, they can produce adequate, stable employment and contribute to effective allocation of resources. Seeking full employment and economic allocation without effective competition, we must move all the way to collectivism. The inherent conflict of interest between each producer group and the community (to repeat) must be reconciled or avoided, either by the discipline of effective intragroup competition or by the dictation of absolute authority from above. 
Monetary and fiscal measures are not a substitute for competition and free-market arrangements but a means for attaining greater over-all security, stability, and efficiency under such institutions. Centralization of monetary and fiscal controls is a sound and necessary means for attaining order and prosperity without other and larger concentration of power. It may be part of a program of total centralization (collectivism) or of a program of systematic decentralization and liberty. It cannot be expected to bring either peace or prosperity out of the economic civil war of monopolized industries and pressure groups. Monetary and fiscal policies are crucially important in the traditional system; they present interesting problems under collectivism. To discuss such policies under syndicalism, however, is to speculate about the workings of a system which is patently and inherently unworkable. 